\title{
CHILDREN'S HOMES AND FOSTER CARE: CHALLENGING DOMINANT DISCOURSES IN SOUTH AFRICAN SOCIAL WORK PRACTICE
}

\section{Nevashnee Perumal \& Madhu Kasiram}

\section{INTRODUCTION}

The dominant view in South Africa and internationally, supported by various legislative tools, is that vulnerable children are best cared for in foster homes as compared to Children's Homes (Kiraly, 2001; Long, 2007; McKay, 2002; Morei, 2002). Legislation in South Africa pertaining to the care and protection of children is presently under review. The Children's Bill consists of two sections: Section 75 and Section 76. Section 75 of the Bill was signed by President Mbeki in June 2006, and is called the Children's Act 38/2005 and Section 76 of the Bill remains before parliament, being referred to as the Children's Amendment Bill [B19-2006]. The Children's Act 38/2005 is not operational as yet and social service providers are still using the Child Care Act 74/1983. It is envisioned that the Children's Act 38/2005 will replace the Child Care Act 74/1983 in 2008 (Jacobs, Shung-King \& Smith, 2005). Should alternative care be necessary for a vulnerable child, the Children's Act 38/2005 prioritises a foster care placement over a child and youth care centre, of which a Children's Home is a part (Section 46(1)(a)). Given the steady decline in traditional family living as a result of, amongst other factors, HIV/AIDS, poverty and unemployment in South Africa, the dominant view of family care being prioritised may not always be a feasible option. Of course, sound social work practice, where individual needs match placement, must always predominate in the decision on the placement of the child. The article critically reviews two alternative care options from an ecological and structural social work framework.

\section{ECOLOGICAL AND STRUCTURAL SOCIAL WORK THEORIES}

The ecological approach pioneered by Germain and Gitterman (1980:5) refers to practice that recognises interactions between living organisms and their environments, stating that "...human beings change their physical and social environments and are changed by them through processes of continual reciprocal adaptation". According to Kasiram (1992), the ecological perspective moves away from linearity, which is mainly used when studying physical and biological entities to a focus on wholeness, interdependence and complementarity to understand people. People act on their environments, thereby shaping the responses of other people, groups, institutions and even the physical environment (Hepworth \& Larsen, 1990:17). Sheafor (1994) adds that the influences are continuous and that people must adapt to these changes in order to cope successfully.

In relating ecological theory to child care, a child who is found to be in need of care in terms of the Children's Act 38/2005 and placed in an alternative care setting is removed from his/her natural environment. The child may be either placed in foster care or a Children's Home and is expected to adapt to this change in environment in order to cope successfully and function in synchrony with this new system (Kasiram, 1992). When this does not happen, imbalance and stress are experienced.

Ecological theory provides one overarching framework to understanding child care in relation to multiple influences that impact on the child and his/her care directly and in interaction (De Vos, 2002). Because of a historical imbalance in resources and service provision across racial lines, 
each of the systemic levels may well fall short of impacting optimally on the child's future development.

In supporting ecological theory, structural social work theory may be seen to accommodate key concerns in child care in South Africa. Structural social work was a term first used by Middelman and Goldberg in 1974 (Mullaly, 1993:122). Relating child care to structural theory, macrosystemic forces are seen to have a powerful influence as follows:

- Different forms of oppression (racism, classism, patriarchy, etc.) are not prioritised, but rather all relevant influences are accorded due concern;

- Various forms of oppression are seen as intersecting with each other at numerous points, creating a total system of oppression;

- The connection between the personal (micro) and the political (macro) is considered significant.

Within the context of recovery from unequal resources for different racial groups in South Africa, structural social work theory accommodates an understanding of how certain families were both oppressed and under-resourced, thereby seriously compromising their ability to care for their children. In this vein Sewpaul (2005) criticises the Draft National Family Policy (2005), citing ideological inconsistencies reminiscent of an apartheid era that continue to plague policy.

In a similar vein Clough (1982:19) states:

"There is a widely held belief that families are the ideal places in which to bring up children or indeed in which any of us, but particularly the dependent, should live. The myth that life is best in families persists in spite of the fact that families are not perfect..."

The authors question how families can fulfil their obligations under conditions of depravity that many find themselves in.

The structural framework may thus be useful in critically appraising the multiplicity of macrosystemic influences as jointly preventing the family from meeting its obligations. Key to these influences are meagre social security, unemployment, economic oppression and exclusion, inequality and poverty (Sewpaul, 2005). Under such circumstances, contrary to what is advocated in the Children's Act 38/2005, the family may not always be the superior option or in the best interests of the child.

\section{CRITIQUE OF THE SOUTH AFRICAN RESPONSE TO ECOLOGICAL THEORY}

In South Africa the ecological approach should be used to support the development and assessment of new policies, Bills and Acts. One such development is the guide entitled "Developmental Assessment of Children, Youth and Families" (Department of Welfare, 2000:27) formulated by the Department of Social Welfare in 2000. The guide refers to the indigenous model of the Native American people and the First Nations people of Canada. It is stated in the guide that this model is the closest to African traditions. The model offers a strengths-based approach using a Circle of Courage that moves away from pathology and focuses on development. The Circle of Courage is based on the four developmental needs/social values of Belonging, which is concerned with a sense of relationship or attachment with other human beings; Mastery, which is concerned with competence and capacity derived from completing developmental tasks that allow one to function effectively; Independence, which concerns a sense of inner control and self-discipline that contribute to responsible decision making; and Generosity, which is linked to a sense of being needed and contributing positively to others' lives. 
When the individual's functioning becomes unbalanced, the circle is seen as being broken (vide ecological framework in viewing child and family dysfunction). The social worker is therefore responsible for identifying the point at which the circle is broken and is responsible for developing a care plan (a broad plan to achieve permanency planning) and an individual development plan (steps to follow in achieving the care plan) to repair the broken circle and in turn ensure optimal functioning. The motivation for this model, according to the Department of Social Welfare (Department of Welfare, 2000), was to resurrect core human values in individuals and families in South Africa. Juxtaposed against this is the White Paper for Social Welfare (1997), which states that "A welfare system (should) facilitate the development of human capacity and self reliance within a caring and enabling socio-economic environment". It is difficult to conceive how such an enabling environment may be nurtured or core human values instilled in South Africa without supportive infrastructure. There is little hope for the four needs cited in the Circle of Courage to be addressed if families continue to ail under poverty-stricken conditions in a residual welfare system. Thus it appears that the ecological framework needs to be supported and complemented by a structural approach to address domination and inequality.

Maluccio, Fein and Olmstead (1986), writing in a London publication, cite the ecological perspective and importance of the biological family in the child's successful alternative placement and reunification. The Children's Act 38/2005 also emphasises family reunification as a critical element in child welfare services. The natural bonds between children in alternative care and their parents/biological family continue to be prominent for parents as well as children long after they are physically separated (Laird in Maluccio et al., 1986). Every effort is required to support the family, to enhance its functioning and to avoid separation. Cordero (2004) affirms that the successful return of children to their biological families is largely dependent on the parent-child attachment relationship being maintained for the duration of the child's placement in alternative care. Sibling relationships are also similarly accorded importance. However, this ideal is difficult to attain in South Africa, given that biological families are rapidly disintegrating for various reasons, some of which include: migrant labour, divorce, teenage pregnancies, infertility, child abandonment, HIV/AIDS and death (Mturi \& Nzimande in Kasiram, Partab \& Dano, 2006). In South Africa kinship care is considered a useful resource to support reunification services and permanency planning, especially in facing the impact of HIV/AIDS on families (Rankopo \& Osei-Hwedi in Kasiram et al., 2006). Thus the dominant social construction of the family and kin significant in the life of a vulnerable child needs to be reconstructed with less emphasis on the blood knot and more emphasis on significant others. Hence, for alternative care to be successful, both the ecological and structural approaches demand that the relationship between the personal (family) and the political (e.g. HIV/AIDS) be accorded due respect.

Another implication flowing from the ecological perspective is the need to view the family as the central unit of service, as people can best be understood and helped within their significant environment (Germain \& Gitterman, 1980). The family is the child's most significant environment. It is here that the child grows up, develops and forms a sense of identity and competence. The family has the potential for providing resources throughout the life process (Briede \& Loffell, 2005). However, many South African families are faced with problems such as crime, substance abuse, family and gender violence and child-headed households, to name but a few significant factors that prevent the environment from contributing optimally towards the child's development. Poverty pre- and post-1994 has led to a vicious cycle as parents who neglect their children have a tendency to think and behave according to their own experiences of being parented and living in poverty (McSherry, 2004; Mullaly, 1993). South African family life 
may therefore not always allow for the nurturing of vulnerable children, necessitating a challenge to the dominant view of family life being best.

Williamson (2002) calls for the revival of the old African tenets of extended familyhood and strong community life. He adds that, given the strenuous challenges brought about by the HIV/AIDS pandemic, the African extended family is perhaps weaker now than a hundred years ago, but the resilience and the spirit of community life is still there for current practitioners to tap into. Familyhood is evident in the practice of ubuntu, loosely translated as "we are who we are because of others". But perhaps it is more a case of resilience in the face of the state not providing support to strengthen the family, as we see grandmothers forsake their own wellbeing and use their old-age pensions to provide for the basic needs of multigenerational families (McKay, 1994). The state views this as a family preservation strategy, but the authors' view is that it may simply be a cheaper option instead of maintaining a child in a child and youth care facility.

McKay (1994:80) refers to children needing sensitive, individual attention, familiar surroundings and intellectual stimulation. Although none of these may be available through living in a Children's Home, it is equally true that a depleted, deprived family environment where parents have died of AIDS cannot hope to provide for these needs.

From an ecological orientation, a major function of the current service delivery system in child welfare is to help families of children in alternative care to restructure their environment. This pertains to the family making its environment more conducive to positive functioning. This may include seeking accommodation in an area less notorious for the availability of drugs and the presence of gangs, so that the placed child may return to a safe environment (Berridge \& Brodie, 1998). Changing the environment may also mean families accessing the assistance of extended family members as a supportive function. From a structural perspective, social workers seek to change the social system and not the individual or family (Mullaly, 1993), since social problems are seen to originate not only from the individual/family, but also from exploitative and alienating practices of dominant groups. So expecting families to survive by making adjustments to, or changing, their living conditions is simply untenable for many a South African family. Consider families living in informal settlements who are displaced by fires. For them to make individual adjustments for their future survival in such a hostile environment is an unrealistic expectation. Infrastructural support must accompany and boost individual efforts, challenging the view that only a structural, or only an ecological, approach will work to empower families. The ecological approach, although encompassing macrosystemic change, does not necessarily view the multi-faceted problems faced by South African families as resulting from oppressive forces of exclusion and disregard. Hence there is need to also adopt a structural perspective in understanding and addressing structural change.

The ecological perspective suggests that the role of the social worker in any case situation should be redefined as that of catalyst or enabling agent - someone who helps the family to identify, create and use resources (Barrat, 2002). The ideal relationship between parents, foster parents and child care staff needs to be one of a partnership in working towards the common goal of returning the child to the family of origin. These functions need to be mutually supportive and complementary (Maluccio et al., 1986). In the South African scenario the social worker cannot perform these functions by adopting only an ecological approach; a structural approach also has to be adopted to challenge deprivation and domination. 


\section{LEGISLATION}

The South African state has drafted important legislation in the fields of juvenile justice, social security and health. However, while social security laws make reference to children, health laws are almost silent on children's special needs and requirements. In view of this criticism civil society made a strong call for a comprehensive piece of legislation to holistically address children's needs - the Children's Bill which, after more than a decade of dialogue and debate, is now reaching finalisation (Jacobs et al., 2005).

\section{CHILD PARTICIPATION IN CHILD AND YOUTH CARE LEGISLATION}

Van Niekerk (2007) calls for increased child participation in policy formulation. Article 4.2 of the African Charter gives a child who is capable of communicating a right to express his/her views and it allows for this in all judicial or administrative proceedings. It is further stated in this provision that "an opportunity shall be provided for the views of the child to be heard either directly or through an impartial representative". Child participation is also addressed in Section 61(1) of the Children's Act 38/2005. Here, although child participation is addressed in two instances, it is encouraged after policies have been formulated, in effect silencing the voice of the child. Children are the "experts in their own lives" and often bring valuable ideas, information and viewpoints that adults may overlook. It is important to listen to the voices of children, respond to their concerns and involve them in decisions that affect their lives (Olson, Sibanda-Knight \& Foster, 2005). This empowerment strategy promotes both a goodness of fit between children and their environments to orchestrate changes in their own lives (ecological approach) and, from a structural perspective, diminishes dominant and oppressive adult influences that may not necessarily address their needs comprehensively. Although children are known and documented to have made submissions for inclusion in the Children's Bill, the Dikwankwetla Action Group set up by the Children's Institute, University of Cape Town is cited in Jacobs et al. (2005) as the only group of children representing four of nine provinces in South Africa to have made submissions for inclusion.

Children's voices need to be heard alongside those of well-meaning adults. Van Niekerk (2007) explains that professionals traditionally work from a position of authority that is based on hardearned years of experience and training. Often times these qualifications may give one an exaggerated sense of expertise that prevents one from being able to acknowledge that the best experts on childhood and youth might at times be children and young people themselves, and that their participation does not necessarily diminish one's expertise and competence, but expands and complements it. The ultimate goal is to act in the best interests of the child with the child understanding and partnering with the social worker in achieving this goal. Social workers need to take the initiative but work alongside the child, particularly when children are unable to put feelings into words (Brandon, Schofield \& Trinder, 1998).

Section 28.1(b) of the South African Constitution is particularly important to children in need of care as it states that "every child has the right to appropriate alternative care when removed from the family environment". If the child is given a voice, then he/she may better adjust to the alternative care arrangement, a simple but key factor that determines success of a placement. From an ecological perspective, this involvement of the child would contribute significantly to the goodness of fit between the child and the new environment, be it a foster home or a Children's Home, which then from a structural perspective needs to have the support of good infrastructure to make the placement work. Thus good social work practice dictating that each child and potential placement be deliberately matched still constitutes best practice. But the 
challenge remains on attaining the best match in the face of deprived families and inadequate infrastructural support.

The Children's Bill focuses on the following three children's rights (Proudlock in Jacobs et al., 2005:16):

- the right to family care, parental care or appropriate alternative care;

- the right to social services;

- the right to protection from abuse, neglect maltreatment and degradation.

Proudlock further indicates that the Children's Bill emphasises the core constitutional and international principle that the child's best interests are of paramount importance. This is particularly relevant in the South African context as the Children's Act 38/2005 will eventually replace the 1983 Child Care Act which, according to Proudlock, was not written from a child rights perspective, but during the apartheid era when South Africa did not have a bill of rights nor a democracy. New legislation must support and "give teeth" to our fledgling democracy and power to children, so that children's rights may be respected and the best alternative care choices made. Given the skewed attention to foster care, whilst offering support to the Children's Home, policies and practice must of necessity address all inconsistencies and prejudices simultaneously so as not to limit progress in either future foster care or institutional care.

\section{FOSTER CARE IN SOUTH AFRICA}

According to the Children's Bill (2005 - 186(1):30), a child is in foster care if the child has been placed in the care of a person who is not the parent or guardian of the child via the processes of a Children's Court. The Bill makes various provisions for the court to extend foster care orders and terminate social work services in the event of there being no reunification services allowing the foster care placement to subsist until the child turns 18.

Foster parents are expected to provide substitute parenting for other people's children (Barrat, 2002). They are further expected to team with the family of origin for the purposes of reunification. The question is whether this is a realistic expectation of the South African foster family. According to Jacobs et al. (2005:33): “...increasing numbers of poverty stricken families who are caring for orphaned children are relying on foster care placements as a way to access the more substantial financial support offered by the foster care grant". This appears understandable in view of the high levels of poverty in the country, the lack of alternative social security options and encouragement from the government to foster children. Thus, foster care as a poverty-alleviation mechanism detracts from the purpose of protecting vulnerable children (Jacobs et al., 2005) and instead is being used to supplement family income, albeit this being meagre and seemingly inconsequential.

Poverty is widespread in South Africa. The question posed by Jacobs et al. (2005) demands an answer: "Why should children who live with foster parents or with relatives require special grants that are of a substantially higher value, and continue for a longer time, than grants for poor children who live with their biological parents?" After 1994 the state acknowledged the "creative" nature of oppressed South Africans in attempting to access social security by defrauding the foster care system. Instead of the state responding innovatively by implementing alternative social security options such as a Basic Income Grant (BIG) or extending the Child Support Grant (CSG) (Lund, 2002, 2007; Makiwane \& Udjo, 2006), it has implemented watchdog systems such as the South African Social Security Agency (SASSA) to root out social security recipient fraudsters (Kasiram et al., 2007). Therefore grandmothers of poverty-stricken 
families obtaining foster care grants where the parent(s) resides in the same home are prosecuted if reported to SASSA. This further disempowers the poor and compounds the problem of poverty. Many parents are terminally ill and by 2010 the estimated number of orphans will be 1,7 million (Raisa Yebo, 2003). In effect then, these strategies address neither poverty nor the child's placement.

Jacobs et al. (2005) accuse the current foster care system of being lopsided and inequitable. It fails to provide adequate support for all vulnerable families. It further introduces a perverse incentive for impoverished families to place their children in the care of others for financial gain. The government needs to competently address poverty among all children in South Africa, whilst also responding to a child's placement needs. Both these concerns suggest the adoption of a both-and approach to repairing inequality from a structural and an ecological perspective to ensure a goodness of fit between child and placement, at micro and/or macro levels. Should foster care be considered a superior option, then foster parents should be trained and equitably remunerated, as is common practice in Australia, New Zealand and the United Kingdom (http://www.child.gov.ab.ca).

\section{CHILD AND YOUTH CARE CENTRES (CHILDREN'S HOMES)}

"A Child and Youth Care Centre is a facility for the provision of residential care to more than six children outside the child's family environment in accordance with a residential care programme/s suited to children in the facility" (Children's Bill [B19-2006]:32). A Children's Home is a constituent part of a Child and Youth Care Centre. The Bill specifies that therapeutic programmes must be designed for children in such alternative care placements, with specialised programmes for vulnerable children such as those with physical and mental disabilities or chronic illnesses.

Historically, as De Vos (1997) points out, Children's Homes were established to care for orphaned, needy and child victims of epidemic outbreaks. Presently many children requiring alternative care come from dysfunctional families (Knutsson, 1997). Mudaly (1985:39) says that "...the child in the Children's Home comes from a life world of lack of appreciation, neglect, inadequate and destructive relationships, impaired communication and even ill treatment". There is an urgent need to address such a child's social development through specialised and professional interventions before irreparable damage is done. Whereas the Bill emphasises the need for therapeutic programmes in a Child and Youth Care facility, there are no supportive training elements offered to foster parents who care for similarly vulnerable children. This is a concern necessitating both an ecological and structural approach to create supportive infrastructure to bolster foster parenting. In the absence of sufficient and suitably trained foster parents, the option of a Children's Home placement may better address the needs of vulnerable South African children, provided that the institution offers such therapeutic programmes on an ongoing and sustained basis.

In South Africa the dominant view, supported by legislation, is that the foster placement as compared to a Children's Home placement is the superior option. Barrat (2002) indicates that for some children who have experienced emotional, physical and/or sexual abuse in their biological family, the closeness of living in another small nuclear family such as a foster family can be frightening; the emotional distance offered in a residential care facility (e.g. a Children's Home) can provide a protective environment for the child. Furthermore, child and youth care workers in Child and Youth Care Centres need to possess a basic qualification in child and youth care (BQCC) from the National Association of Child and Youth Care Workers (NACCW) in order to 
be employed by a Children's Home, whereas a foster parent does not possess any formal qualification nor are they required to undergo any formal, standardised means test to qualify to care for a child (De Vos, 1997; Giese, Meintjies, Croke \& Chamberlain, 2003). De Vos (1997) and Kiraly (2001) confirm that child care staff play a critical role in assisting a child with adjustment, development and re-integration in a Children's Home. But the stark difference in legislative requirements in respect of staff qualifications and the existence of, and insistence on, programmes in both placement options is of concern. The message from government is that, whilst foster care is the preferred option from an ecological perspective, Children's Homes are given much more infrastructural support to carry out their mandate to care for the vulnerable child. This status quo means that child care workers, indeed all social workers, must challenge oppressive dominant, government-imposed discourses to change and introduce legislation and policies that bolster foster care, whilst constantly assessing how policy translates into practice even within the Children's Home. Perhaps then the result will be that each child's placement will be individually determined rather than state imposed by policy commissions and omissions.

\section{CONCLUSION}

If families are considered the heartbeat of our country, why is the state not investing more in them, financially as well as physically, e.g. formal training and support as is done in New Zealand, Australia and the United Kingdom? Caring for vulnerable children should be a highly skilled function as children are considered to be countries' and communities' most valuable assets (Long, 2007; Van Niekerk, 2007). Whilst there exists infrastructural support for Children's Homes, poverty continues to plague South African families. Under these circumstances, it is difficult to conceive of foster care being deemed the best option for South Africa's vulnerable children. Such dominant discourses therefore appear meaningless and counter to promoting the child's best interests and rights. These views need to be challenged using a structural-ecological framework involving all stakeholders to address structural flaws at various systemic levels.

The authors agree with Sewpaul (2005:311) and Sheafor (1994:16-27) that effective social work services need to be underpinned by a structural social justice approach, of working on the micro and mezzo level to empower from "within", whilst offering structural support to sustain efforts at achieving change and development. It is only once service users and providers, along with policy makers, can acknowledge the levels of oppression that are produced through obsolete policies, and accordingly claim redress of imbalance, that a change in the child's future care from a combined ecological and structural perspective can be expected. Thus both options of foster care and Children's homes should simultaneously be afforded meaningful attention, otherwise we shall again experience a prejudiced system that will result in compromised care of the vulnerable child. After all, the best option is the one that best suits the individual needs of the child and family. Given the high levels of burnout related to prolonged exposure to the hardships faced by children and families (Naidoo \& Kasiram, 2006), together with the need to function in a context of stretched or non-existent resources (structural imbalance), this is a major demand. But the need for best practice must prevail.

\section{REFERENCES}

BARRAT, S. 2002. Fostering care: the child, the family and the professional system. Journal of Social Work Practice, 16(2):163-173.

BERRIDGE, D. \& BRODIE, I. 1998. Children's homes revisited. London: Jessica Kingsley Publishers Ltd. 
BRANDON, M., SCHOFIELD, G. \& TRINDER, L. 1998. Social work with children. London: MacMillan Press.

BRIEDE, M. \& LOFFELL, J. 2005. Making social work workable. Children First, 9(61):1718.

CHILD CARE ACT 74/1983. Available: http://www.info.gov.za/gazette/acts. [Accessed: 03/04/2007].

CHILD AND FAMILY WELFARE SOCIETY OF PIETERMARITZBURG. 2004. Annual Report. Pietermaritzburg: City Printing Works.

CHILD AND FAMILY WELFARE SOCIETY OF PIETERMARITZBURG 2007. Kinship Care Report. Pietermaritzburg.

CHILDREN'S ACT 38/2005. Available: http://www.info.gov.za/gazette/acts. [Accessed: 03/04/2007].

DRAFT NATIONAL FAMILY POLICY 2005. Fact sheet: processes and programmes that enhance family life. Available: http://www.socdev.gov.za/ media/2005/april/budget\%20vote/families.htm. [Accessed: 21/05/2007].

CORDERO, A.E. 2004. When family reunification works: data mining foster care records. Families in Society: The Journal of Contemporary Social Services, 85(4):571-580.

CLOUGH, R. 1982. Residential work. London: MacMillan Press Ltd.

DEPARTMENT OF WELFARE. 2000. Developmental assessment of children, youth and families. Republic of South Africa. Available: (www.welfare.gov.za/Documents/1997/wp.htm).

DEVELOPMENT CORPORATION IRELAND. Aids Conference. 2002. Pretoria, South Africa.

DE VOS, M.S. 1997. The social orientation of a child in a children's home. Social Work Practice, 97(2):15-20.

DE VOS, A.S. 2002. Research at Grass Roots: for the social sciences and human sciences professions $\left(2^{\text {nd }}\right.$ ed). Hatfield: Van Schaik Publishers.

DIKWANTWELA ACTION GROUP AND CHILDREN'S INSTITUTE 2004. Children address portfolio committee: Children in action to influence the law. Children First. 8(57):3-7.

FAMILY SUPPORT SERVICES. Available: http://www.services.gov.za. [Accessed: 23/3/07].

GERMAIN, C B \& GITTERMAN, A 1980. The life model of social work practice. New York: Columbia University Press.

GIESE, S., MEINTJIES, H., CROKE, R. \& CHAMBERLAIN, R. 2003. Health and social services to address the needs of orphans and other vulnerable children in the context of HIV/AIDS. Research Report and Recommendations. Children's Institute, University of Cape Town, Cape Town.

HEPWORTH, D.H. \& LARSEN, J.A. 1990. Direct social work practice $\left(3^{\text {rd }}\right.$ ed). Belmont: Wadsworth Inc.

HOCHFELD, T. 2007. Missed opportunities: conservative discourses in the Draft National Family Policy of South Africa. International Social Work, 50(1):79-91.

JACOBS, M., SHUNG-KING, M. \& SMITH, C. (eds) 2005. South African child gauge 2005. Children's Institute, University of Cape Town, Cape Town. 
KASIRAM, M.I. 1992. School social work service delivery: models for future practice, submitted in part fulfilment of the requirements for the degree of Doctor of Philosophy, Durban: Faculty of Arts, University of Durban-Westville.

KASIRAM, M, PARTAB, P. \& DANO, B. (eds) 2006. HIV/AIDS in Africa: the not so silent presence. Durban: Printconnection.

KASIRAM, M., HOLSCHER, D. \& SATHIPARSAD, S. 2007. Understanding multiple perspectives of the child support grant. Paper presentation. Asian, Youth and Childhoods. Lucknow, 22-24, November.

KIRALY, M. 2001. Residential child care staff selection: choose with care. United States of America: Haworth Press Inc.

KNUTSSON, K.E. 1997. Children: noble causes or worthy citizens ( $1^{\text {st }}$ ed). England: Ashgate Publishing Limited.

LONG, S. 2007. Children at the Centre: A guide to supporting community groups caring for vulnerable children. Save the Children, London.

LUND, F. 2002. Consensus \& contestation: the policy for child support in South Africa. Draft Monograph, School of Development Studies, University of Natal.

LUND, F. 2007. Lecture: The Child Support Grant. Address to Social Work Level 4 Students, March 2007.

MAKIWANE, M. \& UDJO, E. 2006. Is the Child Support Grant associated with the increase of teenage fertility in South Africa? Evidence from National Service and Administrative data. Human Sciences Research Council, Pretoria, South Africa.

MALUCCIO, A.N., FEIN, E. \& OLMSTEAD, K.A. 1986. Permanency planning for childrenconcepts and methods. London: Tavistock Publications.

McKAY, A. 1994. No love nor money: institutional child care in South Africa. Critical Health, 46:79-82.

McKAY, P. 2002. Orphans - the case for community care: invest in families for the sake of the children. Children First, 6(42):26-28.

McSHERRY, D. 2004. Critical commentary: Which came first, the chicken or the egg? Examining the relationship between child neglect and poverty. British Journal of Social Work, (34):727-733.

MOREI, N. 2002. The right to family life: courts start to see household diversity. Children First, 6(45):7-10.

MUDALY, B. 1985. The life world of youth in children's homes. The Child Care Worker, 3(4):3-5.

MULLALY, R. 1993. Structural social work: ideology, theory and practice. Toronto: McClelland \& Stewart Inc.

NAIDOO, P. \& KASIRAM, M. 2006. Unplanned pregnancy amongst students at UKZN. Social Work/Maatskaplike Werk, 42(3/4):341-353.

OLSON, K, SIBANDA KNIGHT, Z. \& FOSTER, G. 2005. From faith to action: strengthening family and community care for orphans and vulnerable children in Sub Saharan Africa. Santa Cruz. 
RAISA YEBO, 2003. Available: www.vso.org.uk. [Accessed: 14/03/08].

RANKOPO, M.J. \& OSEI-HWEDI, K. 2006. HIV/AIDS in Botswana: perspectives on community home based care. In: KASIRAM, M, PARTAB, P. \& DANO, B. (ed) HIV/AIDS in Africa: The not so silent presence. Durban: Printconnection: 77-88.

SEWPAUL, V. 2005. A structural social justice approach to family policy. Social Work/Maatskaplike Werk, 41(4):311-323.

SHEAFOR, B.W. 1994. Techniques and guidelines for social work practice $\left(3^{\text {rd }}\right.$ ed). Needham Heights: Simon \& Schuster Inc.

SHEAFOR B.W., HOREJSI C.R. \& HOREJSI G.A. 1997. Techniques and guidelines for social work practice (4th ed). Boston: Allyn and Bacon.

VAN NIEKERK, J. 2007. Child participation - the challenges for child protection workers: The International Society for the Prevention of Child Abuse and Neglect - Special Report, 1(2007):10-11.

WHITE PAPER FOR SOCIAL WELFARE 1997. Available: http://www.welfare.gov.za/Documents/1997/wp.html. [Accessed: 01/06/07].

WILliAMSON, J. 2002. Caring for orphans: A child's place is in a family. Children First, 6(44):24-25.

Ms Nevashnee Perumal, social worker at Pietermaritzburg Child and Family Welfare Society, Professor Madhu Kasiram, School of Social Work and Community Development, UKZN-Howard College Campus, KwaZulu-Natal, South Africa. 